\title{
COMMUNICATION OF TEACHERS AND DEAF STUDENTS IN INTRODUCING SIGN LANGUAGE IN THE EXTRAORDINARY SCHOOL PERTIWI PONOROGO
}

\author{
Dwi Aziz Azizah Agustina \\ Jurusan Komunikasi dan Penyiaran Islam/IAIN Ponorogo, Indonesia \\ Email: azizaagusti12@gmail.com \\ Galih Akbar Prabowo \\ Jurusan Komunikasi dan Penyiaran Islam/IAIN Ponorogo, Indonesia \\ Email : galihakbar77@gmail.com
}

\begin{abstract}
Deafness is a disorder that occurs in the human sense of hearing. Loss of hearing function causes deaf people unable to hear and communicate verbally so that they experience delays in language development. Sign language is used by deaf people as a communication language. Sign language needs to be introduced by teachers of SLB Pertiwi Ponorogo to students with hearing impairments in order to get an agreement on the meaning of the signs used during communication. This research uses a descriptive type of research with a qualitative approach. The results of this study indicate the following: first, the communication carried out by the teacher in introducing sign language uses total communication by means of oral, written, pictures, signs, spelling, and lip-reading. Second, students gave a positive response indicated by a change in attitude following the cues displayed by the teacher. Students give negative responses indicated by emotional changes such as expressions of anger, confusion, silence, and even rejection from students. Third, the communication position in this study lies in the communicator, message, and communicant, namely the communication process barriers, physical barriers, and semantic barriers.
\end{abstract}

\section{Keywords: Communication, Sign Language, Deaf, and Teachers}

\section{INTRODUCTION}

Communication means having a common understanding between the communicator as the sender of the message with the communicant as the recipient of the message. If two people who are communicating have the same meaning, it means that there is no difference in interpreting the message conveyed. So that the communication process can run smoothly and there are no disturbances in communication.

Nonverbal communication, which is a gesture commonly used by people who have communication limitations, such as deaf people. Deafness is a condition where individuals have hearing loss, both partial and total hearing loss. ${ }^{1}$ People who have hearing loss generally also have difficulty communicating verbally. So that deaf people cannot hear and communicate normally.

People with hearing impairment tend to use cue symbols to express their emotions, expressions, and communicate daily. The learning process carried out by deaf people in 
QAULAN, Vol. 2, No.1, Juni 2021

Dwi Aziz Azizah Agustina, Galih Akbar Prabowo Communication of Teachers....

understanding sign language certainly requires stages that are not easy. Communicators with communicants must have an agreement on the meaning of the sign language used at the time of communication. The meaning agreement is made so that there is no mistake in interpreting a nonverbal symbol. Because according to Ronald Adler and George Rodman quoted by Ahmad Sultra Rustan Nurhakki Hakiki, nonverbal communication has an ambiguous nature that can be interpreted in various ways according to the perspective of the person interpreting it. ${ }^{2}$ Everett M. Everett M. Rogers and Lawrence Kincaid quoted by Marhaeni Fajar in their book stated that communication can run in a deep sense between the communicator and the communicant. ${ }^{3}$

Teacher communication with deaf students in introducing sign language is the key to implementing the learning process. The teacher introduces basic sign language until students understand, master, and can slowly use it during communication. Communication can continue when the recipient of the message generates a response to the message conveyed.

This study is focused on examining teacher communication with deaf students at Type B Special Schools (SLB-B) Pertiwi Ponorogo. The communication carried out by the teacher in introducing sign language to students has a decisive position in the student vocabulary process. Good interaction between communication actors will lead to an understanding of sign language so that it can be used as a communication language. The process of recognizing and understanding sign language has a very important essence to research. We can find out how the communication process is carried out by SLB Pertiwi teachers along with the communication barriers that occur. The response of students in receiving the cue symbols given by the teacher determines the continuation of learning. The introduction of sign language is done so that we do not only see the results but need to know the process behind these results.

\section{METHODS}

This research uses a descriptive type of research with a qualitative approach. The author uses a qualitative descriptive approach because the author wants to describe the results of observations and interviews and then assess them so that they get an overview of the research results. While the data processing technique was carried out through several stages, namely observation with the overall observation of communication and interaction between teachers and deaf students in the language specified in SLB Pertiwi Ponorogo. b) interviews with teachers at SLB Pertiwi Ponorogo. c) do documentation by taking photos of learning activities at SLB Pertiwi Ponorogo. d) Data analysis using communication theory, symbolic interactionalism theory, and communication theory to see teacher communication in 
QAULAN, Vol. 2, No.1, Juni 2021

Dwi Aziz Azizah Agustina, Galih Akbar Prabowo Communication of Teachers....

introducing the language in SLB Pertiwi Ponorogo. The data analysis process is carried out by reducing the data, then presenting the data, so that it can be drawn using the theory used.

\section{VERBAL COMMUNICATION}

Verbal communication is the embodiment of language as a medium for exchanging messages. ${ }^{4}$ Symbols or verbal messages are all kinds of symbols that use one or more words. Nearly all speech stimuli fall into the category of verbal messages, namely conscious attempts to connect with other people verbally. The verbal coding system is referred to as language. Language can be defined as a set of symbols with rules to combine various types of symbols that can be used and understood by a particular community. Verbal language is a means of expressing thoughts and feelings experienced by the communicant. The verbal language uses words that represent various aspects of individual. ${ }^{5}$

\section{NONVERBAL COMMUNICATION}

Verbal messages are all cues that are not words. According to Larry A. Samovar and Richard E. Porter, nonverbal communication covers all stimuli except verbal stimuli in a communication setting. ${ }^{6}$ Nonverbal communication is all conveying information without using spoken or written words. Gestures, appearance characteristics, sound characteristics, use of space, and time are also types of nonverbal communication. Nonverbal communication has a communicative nature. Because what humans often do is more communicative than what is said to be far away. Albert Mahrabian research states that when messages convey messages to others, verbal only contributes $7 \%$, voice $38 \%$, and facial expressions $55 \%{ }^{7}$

Vederver et.al quoted by Tito Edi Priandono suggested several forms of non-verbal communication, including 1) Body movements or kinesics, body movements are nonverbal behaviors where communication occurs through one's body movements. These body movements include eye contact, facial expressions, gestures, or postures. 2) Touch, or haptics, is a very ambiguous nonverbal behavior. Because this behavior has a broader meaning depending on the context, relationship, and the way the touch is carried out.8 3) Paralanguange, are nonverbal clues that are sent simultaneously with verbal messages, namely messages that are created when conveying a verbal message. Paralanguage does not focus on studying what is said but focuses on how to say it. Vocal characters include voice pitch, speed of speech, rhythm,

${ }^{4}$ Hakiki, Pengantar Ilmu Komunikasi, 77.

5Ibid., 261.

6Fajar, Ilmu Komunikasi Teori dan Praktik, 52.

${ }^{7}$ Hakki, Pengantar Ilmu Komunikasi, 89.

8Tito Edi Priandono, Komunikasi Keberagaman (Bandung: Rosdakarya, 2016), 193. 
QAULAN, Vol. 2, No.1, Juni 2021

Dwi Aziz Azizah Agustina, Galih Akbar Prabowo Communication of Teachers....

coughing, laughing. ${ }^{9}$ 4) Proksemics, is the use of space and distance during communication. 5) Artifacts, namely methods used to present oneself with the use of objects. Through physical appearance, for example, clothing, accessories, colors, and other objects can convey certain messages. 6) Olfatics, relating to the use of the sense of smell in nonverbal communication. Through the sense of smell, a person can reveal various messages. 7) Chronemics, regarding the selection and use of time in communication. Although it is often neglected, the feedback to the messages conveyed is also influenced by the selection and use of time. ${ }^{10}$

\section{TOTAL COMMUNICATION}

There is a communication system that combines oral communication (verbal communication) and manual (nonverbal communication) which is called total communication. Total Communication is a philosophy or concept that aims to achieve effective communication among deaf people through residual hearing (aural), gestures, fingerspelling, speech, and speech reading. ${ }^{11}$ The purpose of total communication is to capture the language used by the community in a variety of ways including speech, speech reading, gestures, fingerspelling, reading, and writing. ${ }^{12}$ Andreas Dwijosumoroto, quoting Basten Yuni Artika, said that total communication is a concept of education for deaf children which suggests the use of all forms of media communication to improve language skills. In short, it can be said that in total communication there can be distinguished between expressive forms of communication including speech, gesturing, fingerspelling, writing, and pantomimic. Meanwhile, receptive communication components include reading speech, reading cues, fingerspelling, and mimics, using residual hearing and reading. ${ }^{13}$

\section{COMMUNICATION BARRIERS}

The existence of communication barriers will cause interference or noise during communication. So that it causes communication can not run smoothly. ${ }^{14}$ There are three obstacles in the communication process, namely: first, obstacles from the communication process occur in a) Obstacles from the sender of the message, for example, the message

${ }^{9}$ Hakki, Pengantar Ilmu Komunikasi, 90-91.

10Ibid., 92-93.

11Endang Rusyani, "Sistem Komunikasi Anak Tunarungu” (Bandung: Bahan Ajar, Universitas Pendidikan Indonesia, 2019), 54.

${ }^{12}$ Dimmy Mulyana, "Kemampuan Pragmatik Anak Tunarungu Melalui Penerapan Metode Komunikasi Total." (Skripsi, Universitas Negeri Surabaya, 2019), 3.

13Basten Yuni Artika, "Penggunaan Media Animasi Berbasis Pendekatan Komunikasi Total Untuk Meningkatkan Kemampuan Membaca Pemahaman Pada Anak Tunarungu Kelas Dasar V Di SLB-B Yrtrw Surakarta.” (Skripsi, Universitas Sebelas Maret, 2010), Ii.

14Tommy Suprapto, Pengantar Ilmu Komunikasi (Bandung: Alfabeta, 2015), 14. 
QAULAN, Vol. 2, No.1, Juni 2021

Dwi Aziz Azizah Agustina, Galih Akbar Prabowo Communication of Teachers....

conveyed is not clear to the communicator and the communicant. b) Barriers to encryption or symbols, this obstacle occurs because the language used is not clear so that it has more than one meaning. The symbols used between the sender and recipient of the message are not the same or the language used is too difficult. c) Media barriers are obstacles that occur in the use of communication media. For example, radio noise disturbance, electricity disturbance so that you cannot listen to messages. d) Barriers in the code language, this obstacle occurs in the process of interpreting the code by the recipient of the message. f) Obstacles in responding, feedback provided is not timely or unclear so that it can interfere with the communication process. ${ }^{15}$

Second, physical barriers can interfere with effective communication processes. For example, health problems, namely hearing problems. Weather disturbances that cause communication delays and disruption of the communication tools or media used. Third, semantic barriers, namely the words or language used in communication sometimes have multiple different meanings and the message conveyed is not clearly too convoluted. So that it creates an error in interpreting the message. ${ }^{16}$

\section{INTERACTIONALISM THEORY}

Symbolic according to Effendy quoted by Marhaini Fajar said that the theory of symbolic interactionalism is a concept which states that the nature of social interaction is due to communication. Symbolic interaction theory holds that someone acts and acts with others based on the concept of meaning that applies to society. ${ }^{17}$ There are three important concepts in the theory put forward by George Herbert Mead.

The three concepts include: first, society, society consists of a network of interactions where community members give meaning to their own actions and the actions of others by using symbols. Inaction or social interaction involves a three-party relationship. These relationships include body cues, responses, and results. ${ }^{18}$ The meaning that is owned is the result of interactions with other people. Second, self means that self or self is a characteristic of Humans. Self, how, our way, can see ourselves, others. This can be done through the process of "role-taking" or using other people's perspectives in seeing ourselves. This is what guides individuals to have a self-concept. Self-concept is our total perception of how other people see us. Self-concept formation can be accessed by the surrounding community. ${ }^{19}$ Thoughts, thinking

\footnotetext{
15Fajar, Ilmu Komunikasi Teori dan Praktik, 62-63.

16Ibid.

${ }^{17 E d i s o n ~ H u t a p e a, ~ " I d e n t i t a s ~ D i r i ~ M e l a l u i ~ S i m b o l ~-~ S i m b o l ~ K o m u n i k a s i ~(S t u d i ~ I n t e r a k s i o n a l i s m e ~ S i m b o l i k ~}$ Komunitas Pemakai Narkoba di DKI Jakarta)," Bricolage (Vol.2 No. 1), 4.

${ }^{18}$ Edison Hutapea, "Identitas Diri Melalui Simbol - Simbol Komunikasi (Studi Interaksionalisme Simbolik Komunitas Pemakai Narkoba di DKI Jakarta)," Bricolage (Vol.2 No. 1), 4. 19Ibid., 229.
} 
QAULAN, Vol. 2, No.1, Juni 2021

Dwi Aziz Azizah Agustina, Galih Akbar Prabowo Communication of Teachers....

is a process of activities that occur within oneself. The ability to use significant symbols allows oneself to think. In giving meaning to symbols used based on how one thinks and acts on these symbols. ${ }^{20}$

Humans act towards humans based on the meaning that other people give them. This assumption explains that human behavior contains meaning that can be studied through psychological and sociological explanations. Its true meaning is created through interactions between humans. According to Mead, meaning only exists when people have the same interpretation of the symbols they exchange in interactions. ${ }^{21}$ The ultimate goal of this symbolic interaction is to interpret the symbol or symbol based on a mutual agreement that is bound in a certain area. ${ }^{22}$

\section{SIGN LANGUAGE}

Language is included in the type of nonverbal communication. Sign language emphasizes the combination of body language, gestures, arms, and arms, as well as facial expressions to convey thoughts. Sign language is one of the ways of communication used by persons with disabilities to receive and understand messages. ${ }^{23}$ According to Chairul Anam, sign language is a language that is carried out using body movements and facial expressions as a symbol of the meaning of language. Usually, in language, deaf people combine hand shapes, hand expressions, body arms, facial expressions to express their thoughts. From this explanation, it can be ignored that sign language is the language used through body movements and facial expressions specifically for deaf people. ${ }^{24}$

In Indonesia, there are two system requirements, namely the Indonesian Sign Language System (SIBI) and Indonesian Sign Language (BISINDO). ${ }^{25}$ SIBI is an official sign language developed by the government for deaf people. The fundamental difference between SIBI and BISINDO is in the manner of spoken and written Indonesian in the form of sign language. So in SIBI it is hinted word for word even using the implied affix. Meanwhile, BISINDO

\footnotetext{
20Ibid., $230-231$.

${ }^{21}$ Richard Wes Lynn H. Turner, Pengantar Teori Komunikasi Analisis dan Aplikasi (Jakarta: Selemba Humanika, 2007), 98 - 100.

${ }^{22}$ Hutapea, Jurnal Bricolage Vol. 2 No.1, 5.

${ }^{23}$ Diah Rahmawati, Panduan Bahasa Isyarat untuk Pendamping Penyandang Tuli (Tangerang, Albasil Aksara, 2018), 15.

${ }^{24}$ Bahasa Isyarat Indonesia (BISINDO) Dalam Komunikasi," INKLUSI, (Vol. 2, Juli - Desember 2015, UPI Bandung), 223.

${ }^{25}$ Silva Tenrisara Isma, “Meneliti Bahasa Isyarat Dalam Perspektif Varian Bahasa Indonesia," Kongres Bahasa Indonesia, 3.
} 
QAULAN, Vol. 2, No.1, Juni 2021

Dwi Aziz Azizah Agustina, Galih Akbar Prabowo Communication of Teachers....

does not use spoken and written Indonesian grammar. But by taking the meaning of the sentence, so that the sentence structure is reversed in writing. ${ }^{26}$

The following is the alphabet and numbers in SIBI:

SIBI Alphabet Sign Language. ${ }^{27}$

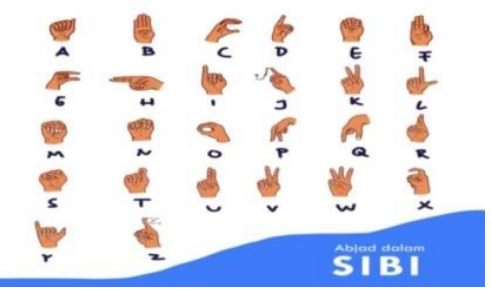

Sign Language of SIBI Numbers. ${ }^{28}$

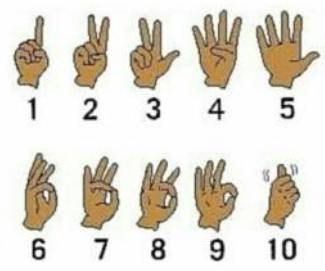

The following is the alphabet and numbers in SIBI:

BISINDO Alphabet Sign Language. 29

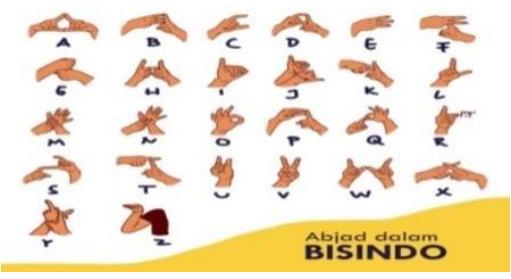

BISINDO Number Sign Language. ${ }^{30}$

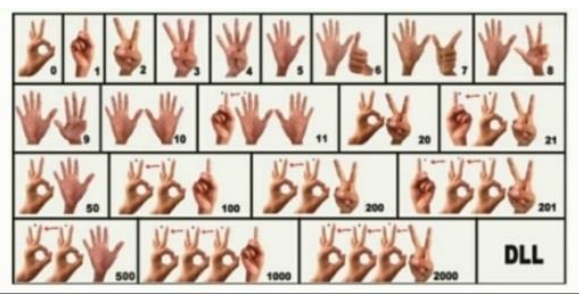

\section{DEAF}

Deafness is a condition of someone who has hearing loss so that the report can hear either partially or completely. The term deaf has represented society as a term for people who are hearing impaired or deaf. Deaf comes from the word "tuna" which means "disabled" and "deaf" which means "hearing". Different circumstances make them communicate in different languages, that is, in different languages. Deaf people are physically, cognitively, psychologically, just like normal humans. This is because there are people with disabilities who have a high IQ level or a genius. But some have a low IQ level to abnormalities in other things, such as brain

26Rahmawati, Panduan Bahasa Isyarat untuk Pendamping Penyandang Tuli, 28.

${ }^{27}$ Sumber Gambar diakses pada 18 September 2020, jam 08:53 dilaman https://www.klobility.id/amp/perbedaan-bisindo-dan-sibi.

${ }^{28}$ Sumber gambar diakses pada 20 September, jam 11:49 dilaman https://images.app.goo.gl/vCCHEvctDnMj4gz7.

29Ibid, https://www.klobility.id/amp/perbedaan-bisindo-dan-sibi.

${ }^{30}$ Sumber gambar diakses pada 20 September, jam 11:50, dilaman https://www.google.com/imgres?imgurl=https\%3A\%2F\%2Fmeenta.net\%2Fwpcontent\%2Fuploads\%2F05\%2Fbisindo-angkaa-1024x6841024x684.jpgdanimgrefurl=https\%3A\%2F\%2Fmeenta.net\%2Fbahasa-isyaratbisindo\%2F\&tbnid=qgGNbCcRPwo-dM\&vet=1\&docid=tpwoLecpuufCfM\&w=1024\&h=684\&hl=inID\&source $=\mathrm{sh} \% 2 \mathrm{Fx} \% 2 \mathrm{~F} \% 2 \mathrm{fIM}$. 
QAULAN, Vol. 2, No.1, Juni 2021

Dwi Aziz Azizah Agustina, Galih Akbar Prabowo Communication of Teachers....

paralysis, mental retardation, and so on. ${ }^{31}$ The thing that distinguishes it is the communication that is carried out. Language skills and speech problems for deaf people. These difficulties have an impact not only on a lack of sensory input but also a disturbance in the distraction of both friends and family.

The development of deaf people is as follows: first, language development and communication of deaf children having difficulty speaking the spoken language. Vocabulary mastery is also not as good as the children can hear. First, straightforward and easier to implement grammatical communications is the necessary language. Second, the social and emotional development of people with hearing impairments, namely having a high sense of curiosity and curiosity about the surrounding environment. Some of the characteristics that are often encountered in deaf children include egocentricity, impulsive nature, namely doing something suddenly without planning, having a rigid attitude, and having a high sense of doubt and worry. Third, cognitive development, namely language development of children with hearing impairments affecting their cognitive development. Fourth, the development of the gross motor system and fine motor deafness has no difference with normal children. ${ }^{32}$

\section{TEACHER}

A teacher is someone who has dedicated his life to teaching science, educating, and directing his students to understand what has been taught. In this case, the teacher does not only teach formal education, but also moral education. So that students have good character. The teacher is the name for someone's profession who devotes himself to education through patterned, formal, and systematic interactions. 33

According to Law no. 14 of 2005, teachers have the meaning of professional educators who have the main task of educating, teaching, guiding, training, training, assessing students through formal education to secondary education. ${ }^{34}$ In particular, teachers are required to provide professional services to students so that learning objectives can be achieved. ${ }^{35}$

The teacher has an important role in the field of education, while the role of the teacher is as follows: 1) As a teacher, that is, a person who teaches knowledge to their students. 2) As an educator, namely a person who educates his students to behave following the norms prevailing in society. 3) As a guide, a person who directs his students to stay on the right track according to educational goals. 4) As an example, that is a person who provides a good example and role

\footnotetext{
${ }^{31}$ Rahmawati, Panduan Bahasa Isyarat untuk Pendamping Penyandang Tuli, 2-3.

32Ibid., 11.

33Dewi Safitri, Menjadi Guru Profesional (Riau: PT. Indragiri Dot Com, 2019), 5-6.

34Ibid., 9-10.

35Khusnul Wardana, Guru Sebagai Profesi (Yogyakarta: Deepublish, 2019), 69-70.
} 
QAULAN, Vol. 2, No.1, Juni 2021

Dwi Aziz Azizah Agustina, Galih Akbar Prabowo Communication of Teachers....

model for his students. 5) As an administrator, a person who keeps track of the progress of his students. 6) As an evaluator, the person who evaluates the learning process of their students.

The role of the teacher also teaches students to become human beings who can have good morals. ${ }^{36}$ Wijaya quoted by Shilphy A. in his book said that teachers not only have moral responsibility but also non-moral responsibility for their students. ${ }^{37}$

\section{TEACHER COMMUNICATION IN INTRODUCING SIGN LANGUAGE TO DEAF STUDENTS}

The way the teacher communicates in introducing the sign language to deaf students using the total communication type. Total communication is a communication system that combines verbal and nonverbal communication. This total communication aims to express the language used by the community in various ways including speaking, reading utterances, gestures, fingerspelling, reading, and writing. ${ }^{38}$

The following describes the teacher's total communication in introducing sign language to students with hearing impairments at SLB Pertiwi Ponorogo with a combination of verbal and nonverbal communication as follows: 1) Verbal communication, communication that exists between the teacher and students who are deaf in sign language at SLB Pertiwi Ponorogo, one of which uses communication. verbal. Verbal communication includes communication, communication, and writing. The use of this communication aims to optimize residual hearing and train students to communicate. 39

Use verbal communication is a strategy used by teachers in improving students' language skills. This strategy is used so that students do not need to master the language but can use language as a verbal symbol. This is by the theory put forward by Berelson and A. Steiner that communication is the transmission of information, ideas, emotions, skills, and so on by using symbols such as words, pictures, graphics, and numbers. The act of transmission is referred to as communication. ${ }^{40}$ 2) Nonverbal communication, the type of non-verbal communication used by the teacher of SLB Pertiwi Ponorogo in introducing language has a dominant role during the communication. Learning deaf students prioritizes visual media to support their understanding. The teacher uses visual media such as visual aids and pictures in introducing language to the students of SLB Pertiwi Ponorogo. This visual media is used to anticipate the failure of verbal communication used by the teacher. This visual media will help

36Safitri, Menjadi Guru Profesiona, 20-21.

${ }^{37}$ Shilphy A. Octavia, Sikap dan Kinerja Guru Profesional (Yogyakarta: Deepublish, 2019), 28.

38Mulyana, Jurnal Pendidikan Khusus Kemampuan Pragmatik Anak Tunarungu Melalui Penerapan Metode Komunikasi Total, 3.

${ }^{39}$ Mulyana, Ilmu Komunikasi Suatu Pengantar, 68.

40Ibid., 69. 
QAULAN, Vol. 2, No.1, Juni 2021

Dwi Aziz Azizah Agustina, Galih Akbar Prabowo Communication of Teachers....

the communication of the teachers of SLB Pertiwi Ponorogo during the lesson. So that teachers can create an effective and efficient learning process.

In this study, the teachers of SLB-B Pertiwi Ponorogo used nonverbal forms of communication which were kinesic and paralanguage types. The following is each explanation: a) Kinesics, which is included in kinesics, is first, eye contact or eye contact in the eye contact communication activities of the teacher of SLB Pertiwi Ponorogo in introducing sign language, which functions as a regulator and expresses expressions As stated by Deddy Mulyana, eye contact functions as a regulator and expressive. Eye contact is a pendant, which is to tell others that the communicator will have a relationship with the communicant or will even avoid it. Expressive function, to convey to the communicant how the communicator feels about him. ${ }^{41}$ Second, Facial expressions such as smiling, enthusiasm, joy, anger are always used by the SLB Pertiwi Ponorogo teacher when communicating with students. The use of facial expressions is carried out so that students understand the teacher's condition during the message delivery process. This facial expression is used to make communication more expressive. ${ }^{42}$ Third, Gesture in this case the teacher of SLB Pertiwi Ponorogo always uses gestures when communicating with deaf people. Cues in communication activities carried out by the teacher are more focused on lip movements when speaking. This pressing of the lips is done so that deaf students can read lips to understand the message conveyed. b) Paralanguang in this study, the teacher plays the voice intonation to express his emotions when communicating with deaf students. Such as the intonation of shouting, angry, happy, sad, annoyed which is used in conjunction with the teacher's facial expression.

Based on the theory of nonverbal communication put forward by Deddy Mulyana, nonverbal behavior functions as a repeater of verbal behavior, reinforces or complements verbal behavior, replaces verbal behavior, nonverbal behavior can regulate verbal behavior, nonverbal behavior can deny verbal behavior. ${ }^{43}$ In this study, the nonverbal behavior of SLB Pertiwi Ponorogo teachers in sign language recognition serves to repeat, strengthen, and regulate verbal behavior.

A combination of verbal and nonverbal communication produces total communication. Total communication is communication suitable for deaf students. This communication is used simultaneously during the learning process. The total communication used by the teacher during the learning process can be described as follows: the teacher introduces signs such as apples, guava, and flowers to deaf students using total communication. First, the teacher shows

41 Ibid., 373.

${ }^{42}$ Hakiki, Pengantar Ilmu Komunikasi, 96.

43Mulyana, Ilmu Komunikasi Suatu Pengantar, 349-350. 
QAULAN, Vol. 2, No.1, Juni 2021

Dwi Aziz Azizah Agustina, Galih Akbar Prabowo Communication of Teachers....

a picture of apples and guava. The teacher introduces the picture by verbally saying "apple and guava" by emphasizing the expression on the lips. Followed by a hand gesture hinting at the words apple and guava. The teacher then introduced the words apple and guava into written form.

The total communication used by the teacher in sign language recognition is by the stages of using total communication. The first stage is the initial stage, at this stage, the teacher does not require students to be able to speak, but can move their mouths or say words when giving signals. In the second stage, namely the amalgamation stage, deaf students are required to be able to combine signs with speaking. The strategy for using total communication in learning is that when the introduction of sign language is done, the teacher introduces basic words and signs at the smallest grade level, namely grade I SDLB-B Pertiwi. Then the teacher begins to introduce sentences according to the order in Indonesian at the next grade level such as grades II and III.

\section{STUDENT RESPONSES IN RECEIVING SIGN LANGUAGE DELIVERED BY THE TEACHER}

The communication that exists between teachers and deaf students involves a two-way interaction. It appears that students give responses in the form of responses in receiving the cue symbols conveyed by the teacher. In this study, students as communicants showed various responses. Student responses are in the form of positive and negative responses to the messages conveyed by the teacher. The responses given by students in this interaction when viewed from the theory of symbolic interactionalism will involve three concepts of George Herbert Mead's thoughts, namely: 1) Society (society), in the communication relationship carried out by the teacher when viewed from the first concept of thought it involves interaction with the community. Researchers describe this interaction as occurring in small groups. The interactions carried out by the teacher occur in the school environment, namely in the classroom between teachers and deaf students. The teacher introduces and forms the concept of the meaning of sign language that is conveyed to deaf students.

This social interaction involves the relationship of three parties, including a) Initial signals (gestures), the teacher gives guava and apple cues to students. These gestures are demonstrated at the same time as the words "guava and apple" are pronounced. b) Responses (responses), students respond by following what has been demonstrated by the teacher. Students also say the word "guava" but it sounds more like the word "bamboo" and the word "apple" is only heard the back word that sounds "mop" when pronounced by a deaf child. c) The results, when viewed from the responses given, mean that students can understand that the cues conveyed by the teacher have the meaning of guava and apples. 2) Self (self), the 
QAULAN, Vol. 2, No.1, Juni 2021

Dwi Aziz Azizah Agustina, Galih Akbar Prabowo Communication of Teachers....

interaction that exists between teachers and deaf students will involve the self-concept of how the teacher as a communicator will interpret the responses given by students in response to the messages conveyed. In this concept, the teacher as a communicator will take the role of being a listener of the message conveyed by himself. The teacher tries to see how he introduces cue symbols from the student's perspective whether these cues can be understood by himself. According to George Herbert Mead, communicators can imagine how it feels to receive their own message so that they can empathize with the listener and take the role of the listener. 3) Mind (thoughts), the existence of social interactions and self-concepts that have been done by teachers and deaf students will affect their thoughts informing meaning. The teacher's interpretation and way of thinking about the deaf student's response will make the teacher know the meaning of the student's actions or responses. The teacher will know the level of student understanding of sign language based on the responses given by students. Students will also experience a thought process in translating the cue symbols conveyed by the teacher so that it will determine the response given by students.

Mead's concept of self and mind are basically related to each other at the time of the formation of the message. Both of these concepts occur in the communicators and communicants which can occur when they are interacting. In this study, the three concepts of George Herbert Mead's thoughts occur in the interaction between teachers and deaf students during sign language recognition. So in this learning interaction, there has been an agreement on the meaning between the teacher and deaf students regarding the signals being conveyed. The agreement of meaning can be seen from the responses given by students at the time of introduction of sign language by the teacher. This meaning agreement when viewed from the communication theory put forward by Everett M. Rogers and Lawrence Kincaid gives a sign that the communication that exists between teachers and deaf students has a deep understanding of the signals conveyed.

The data exposure was a positive response given by deaf students in receiving sign symbols. Students show a positive response by following the cues displayed by the teacher. Researchers concluded from the results of interviews conducted with teachers of SLB Pertiwi Ponorogo as a whole, the negative responses of deaf students were shown by emotional changes such as anger, annoyance, confusion, silence, and even rejection from students. If it is related to the response theory expressed by Marhaeni Fajar, feedback plays an important role. Feedback will determine the continuation or cessation of communication. ${ }^{44}$ The negative feedback that is

44Fajar, Ilmu Komunikasi Teori dan Praktik, 59. 
QAULAN, Vol. 2, No.1, Juni 2021

Dwi Aziz Azizah Agustina, Galih Akbar Prabowo Communication of Teachers....

given is evidence of stopping communication which can be determined from the negative response given by the communicant.

\section{COMMUNICATION BARRIERS TO TEACHERS IN INTRODUCING LANGUAGE REQUIREMENTS TO DEAF STUDENTS}

The existence of communication barriers made by deaf teachers and students in the introduction of sign language at SLB Pertiwi Ponorogo makes the communication process unable to run effectively and efficiently. Communication barriers occur first, barriers to communication processes that occur in several elements of communication, namely: a) Barriers to sending messages or communicators, these obstacles occur to communicators as senders of messages, this occurrence of communication barriers are caused by the lack of the teacher's ability to master and remember the language cue or hints at spelling. This has an impact on teachers who are unable to encode ideas, ideas, information into messages that can be conveyed to the communicants. The communicator cannot formulate his thoughts and feelings into symbols or language that the communicant will understand. This barrier can be overcome by teachers by practicing independent sign language skills. b) obstacles in the encoding or symbol of the message, not all messages conveyed by the communicator have a signal and can be hinted at. Such as people's names, long sentences, and abstract words. Problems with this message symbol can be a barrier to the communication process between teachers and deaf students. The solution given by the teacher to solve this problem is usually by spelling the word or by showing a gesture that can represent the message to be conveyed. b) Barriers in coding, the message conveyed by the teacher is ambiguous which can be interpreted in various ways according to the perceptions of each person who interprets it. The interpretation of this message is influenced by the background, social, education, and culture of everyone involved in communication activities. ${ }^{45}$ This obstacle occurs in deaf students as communicants in this study. Each student has a different interpretation of the cues introduced by the teacher. c) Obstacles to message recipients, these obstacles occur to message recipients who are unable to decode or interpret the message by the communicator. This obstacle occurs because deaf students cannot interpret the signal message that has been conveyed by the teacher of SLB Pertiwi Ponorogo. This problem can be an obstacle in the learning process of the students of SLB Pertiwi Ponorogo.

Second, physical barriers, occur to the communicant as the recipient of the message. Communicants in this study have problems in hearing and verbal communication. The communicants in this study were deaf students, in this condition the communicants could not

45Mulyana, Ilmu Komunikas Suatu Pengantar, 272. 
QAULAN, Vol. 2, No.1, Juni 2021

Dwi Aziz Azizah Agustina, Galih Akbar Prabowo Communication of Teachers....

hear and speak verbally. Physical barriers suffered by communicants are the biggest inhibiting factor in the learning and communication process of deaf students. Third, semantic barriers, in this study semantic barriers occur in long-shaped languages. As said the deliberation is difficult to convey by the teacher of SLB Pertiwi Ponorogo. Basically, this semantic barrier can also occur in the communication process which lies in the barrier to using symbols. Barriers to using symbols can also be classified into semantic barriers, namely in terms of language use.

Communication disorders in this study can occur in all elements of communication. The disturbance occurs in communicators, messages, and communicants. Communication disorders between teachers and deaf students in introducing sign language are by the theory put forward by Shannon and Weaver, namely communication disorders occur when there is an intervention to one of the communication components. So that the communication process cannot run effectively. 46

\section{CONCLUSION}

This paper discusses the communication of teachers and students with hearing impairments in introducing sign language at the Pertiwi Ponorogo Special School (SLB), from the analysis obtained first, teacher communication in introducing sign language to deaf students using total communication. This total communication involves verbal and nonverbal communication, namely oral, written, pictures, gestures, spelling, reading lips, or spoken language, . Second the responses given by students with hearing impairments were: positive responses, indicated by a change in attitude by imitating the symbols displayed by the teacher. Negative responses, indicated by emotional changes such as expressions of anger, confusion, silence, and even rejection from students. The interactions that exist between teachers and students are by the theory of symbolic interactionalism, namely the existence of the relationship between society, self, and mind which can affect the process of forming meaning. Third, communication barriers between teachers and students with hearing impairments occur in communicators, messages, and communicants. Communication barriers can be classified as occurring in communication process barriers, physical barriers, and semantic barriers.

\section{REFERENCES}

Artika, Basten Yuni. Penggunaan Media Animasi Berbasis Pendekatan Komunikasi Total Untuk Meningkatkan Kemampuan Membaca Pemahaman Pada Anak Tunarungu Kelas Dasar V Di SLB-B Yrtrw Surakarta. Universitas Sebelas Maret: 2010.

46Ibid., 40. 
QAULAN, Vol. 2, No.1, Juni 2021

Dwi Aziz Azizah Agustina, Galih Akbar Prabowo Communication of Teachers....

Fajar, Marhaeni. Ilmu Komunikasi dan Praktik. Yogyakarta: Graha Ilmu, 2009.

Hakiki, Ahmad Sultra Rustan Nurhakki. Pengantar Ilmu Komunikasi. Yogyakarta: Deepublis Group Penerbit CV Budi Utama, 2017.

https://images.app.goo.gl/vCCHEvctDnMj4gz7.

https://www.google.com/imgres?imgurl=https\%3A\%2F\%2Fmeenta.net $\% 2 \mathrm{Fwp}-$

content\%2Fuploads\%2F05\%2Fbisindo-angkaa-1024x684-

1024x684.jpgdanimgrefurl=https\%3A\%2F\%2Fmeenta.net\%2Fbahasa-isyarat-

bisindo\%2F\&tbnid=qgGNbCcRPwo-

dM\&vet=1\&docid=tpwoLecpuufCFM \&w=1024\&h=684\&hl=in-ID\&source=sh $\% 2 F x \% 2 F \% 2 F i M$.

https://www.klobility.id/amp/perbedaan-bisindo-dan-sibi.

Hutapea, Edison. "Identitas Diri Melalui Simbol-Simbol Komunikasi (Studi Interaksonalisme Simbolik Komunitas pemakai Narkoba di DKI Jakarta)", Pilihan Jurnal Bricolage, 1 - 14, Jakarta: Universitas Bunda Mulia, 2013.

Isma, Silva Tenrisara."Meneliti Bahasa Isyarat Dalam Perspektif Varian Bahasa Indonesia." Pilihan Jurnal Kongres Bahasa Indonesia, 1 - 14, td, td.

Lakshita, Nattaya. Belajar Bahasa Isyarat Untuk Anak Tunarung. Yogyakarta: Javalitera, 2012.

Morissan. Teori Komunikasi Individu Hingga Massa. Jakarta: Kencana, 2013.

Mulyana, Deddy. Ilmu Komunikasi Suatu Pengantar. Bandung: PT. Remaja Rosdakarya, 2016.

Mulyana, Dimy. Jurnal Pendidikan Khusus Kemampuan Pragmatik Anak Tunarungu Melalui Penerapan Metode Komunikasi Total. Universitas Negeri Surabaya, 2019.

Mursita, Rohmah Ageng. "Respon Tunarungu Terhadap Penggunaan Sistem Bahasa Isyarat Indonesia (SIBI) Dan Bahasa Isyarat Indonesia (BISINDO) Dalam Komunikasi." Pilihan Jurnal INKLUSI, 1 - 12, Bandung: UPI, 2010.

Octavia, Shilphy A. Sikap dan Kinerja Guru Profesional. Yogyakarta: Deepublish, 2019.

Priandono, Tito Edi. Komunikasi Keberagaman. Bandung: Rosdakarya, 2016.

Rahmawati, Diah. Panduan Bahasa Isyarat untuk Pendamping Penyandang Tuli. Tangerang, Albasil Aksara, 2018.

Rusyani, Endang. Sistem Komunikasi Anak Tunarungu. Bandung: Bahan Ajar, Universitas Pendidikan Indonesia, 2019.

Safitri, Dewi. Menjadi Guru Profesional. Riau: PT. Indragiri Dot Com, 2019.

Soyomukti, Nurani. Pengantar Ilmu Komunikasi. Jogjakarta: Ar-Ruzz Media, 2012.

Suprapto, Tommy. Pengantar Ilmu Komunikasi. Yogyakarta: Caps, 2011.

Turner, Richard Wes Lynn H. Pengantar Teori Komunikasi Analisis dan Aplikasi. Jakarta: Selemba Humanika, 2007.

Wardana, Khusnul. Guru Sebagai Profesi. Yogyakarta: Deepublish, 2019. 